\title{
Peningkatan Gizi Masyarakat melalui Pemberian Nuget Formula Ikan Layang dengan Penambahan Daun Kelor terhadap Kadar Seng Ibu Hamil Kurang Energi Kronik
}

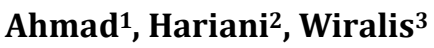 \\ 1,2,3Poltekes Kemenkes Kendari-Sulawesi Tenggara, Indonesia \\ E-mail: ahmad_poltekes232@gmail.com
}

\begin{abstract}
Article Info Abstract

Article History

Received: 2021-11-20

Revised: 2021-12-15

Published: 2022-01-16

The aim of the study was to determine the effect of giving fly fish nugget formula with the addition of Moringa leaf flour on zinc levels of pregnant women with chronic energy deficiency in Puuwatu District, Kendari City. , 40 grams of white chicken eggs, 5 grams of sugar, 10 cloves of garlic, 1 teaspoon of fine salt, 1 pack of ground pepper, 50 grams of cooking oil and the addition of 45 grams of Moringa leaf flour. kcal, 178.2

Keywords:

Pregnant Women; grams of protein, 19.0 grams of fat, 77.5 grams of carbohydrate and $5.4 \mathrm{mg}$ of zinc.

KEK;

Nuggets; While the results of the Proximate test were $20.613 \%$ water content, $0.642 \%$ ash content, $8.081 \%$ protein, $18.822 \%$ fat, $3.5 \%$ crude fiber and $9.390 \%$ zinc. The results of Zinc. laboratory tests for zinc levels in pregnant women with SEZ are an average of 200.50 $\mathrm{mg} / \mathrm{L}$, increasing to an average of $212.63554 \mathrm{mg} / \mathrm{L}$. This shows that there is an increase in zinc levels in CED pregnant women, which is an average of $12.6 \mathrm{mg} / \mathrm{L}$, the test results show a significant effect with a sign value of $0.034(<0.05)$, and an average weight gain of $6.86 \mathrm{~kg}$ and LILA an average of $0.61 \mathrm{~cm}$.
\end{abstract}

Artikel Info
Sejarah Arti
Diterima: 2021-1
Direvisi: 2021-12
Dipublikasi: 2022

Kata kunci:
Ibu Hamil;
KEK;
Nugget;
Seng.

\section{Abstrak}

Penelitian bertujuan untuk mengetahui pengaruh pemberian formula nugget ikan layang dengan penambahan tepung daun kelor terhadap kadar seng ibu hamil kurang energy kronik di Kecamatan Puuwatu Kota Kendari, Hasil penelitian, telah diperoleh bahwa formula nugget untuk ibu hamil KEK dengan konsentrasi 700 gr ikan layang, 50 gr tepung terigu, 40 gr telur ayam bagian putih, gula pasir $5 \mathrm{gr}$, bawang putih 10 siung, garam halus 1 sendok the, lada bubuk 1 bungkus, minyak goreng 50 gr dan penambahan tepung daun kelor 45 gr, dari formula nugget tersebut diperoleh nilai gizi energi 1197 kkcal, protein 178,2 gr, lemak 19,0 gr, hidrat arang 77,5 gr dan zink 5,4 mg. Sedangkan hasil uji Proksimat diperoleh kadar air 20,613 \%, kadar abu 0,642\%, protein 8,081\%, lemak 18,822 \%, serat kasar 3,5 \% dan Zink 9,390\%. Hasil uji laboratorium untuk kadar seng pada ibu hamil KEK rata-rata 200,50 mg/L naik menjadi rata-rata $212,63554 \mathrm{mg} / \mathrm{L}$. Hal ini menunjukkan bahwa ada kenaikan kadar seng pada ibu hamil KEK yaitu rata-rata $12,6 \mathrm{mg} / \mathrm{L}$, hasil uji statistik menunjukkan terdapat pengaruh yang signifikan dengan nilai sign $0,034(<0,05)$, dan terjadi kenaikan berat badan rata-rata $6,86 \mathrm{~kg}$ dan LILA rata-rata $0,61 \mathrm{~cm}$.

\section{PENDAHULUAN}

Penduduk yang berkualitas merupakan modal dasar pembangunan berkelanjutan (Suntainable Development Goals). Kualitas penduduk dari aspek kesehatan dimulai dari konsepsi hingga anak balita, untuk itu penting memperhatikan kesehatan ibu hamil sebagai awal kehidupan seorang manusia. Salah satu faktor penting kesehatan ibu hamil adalah terpenuhinya semua kebutuhan gizi termasuk unsur mineral seng (zn), kebutuhan seng pada ibu hamil meningkat secara signifikan untuk pertumbuhan jaringan dan plasenta. Defisiensi seng berkaitan dengan kurang energi kronik dan anemia pada ibu hamil. RISKESDAS 2018 menggambarkan terjadi peningkatan ibu hamil anemi di Indonesia sebesar $48,9 \%$, seng merupakan zat gizi mikro yang mempengaruhi metabolisme zat besi. Hasil penelitian Thamrin A, dkk, 2019, ada hubungan antara asupan seng dengan haemoglobin sebesar $\mathrm{p}=0,015$.

Caulfiled (1998), memperkirakan 82\% wanita hamil di seluruh dunia mengalami kekurangan seng, di Indonesia belum ada data nasional mengenai kekurangan seng pada ibu hamil, walau demikian data dari survei terserak memberikan indikasi adanya masalah kekurangan seng. Sebuah studi di Nusa Tenggara Timur pada tahun 1996 menemukan rata-rata 71 persen ibu hamil mengalami kekurangan seng, sebagian besar kasus kekurangan seng termasuk ke dalam kekurangan ringan-sedang dan tidak terbatas pada kalangan sosial ekonomi rendah saja, penelitian pada tikus menunjukkan tikus yang mengalami kekurangan seng sejak sebelum kehamilan hingga beberapa minggu pertama 
kehamilan akan mengalami keguguran dan menimbulkan cacat, kecacatan dapat terjadi pada kelainan fungsi organ, jaringan seperti syaraf, dan sistem imun. Secara mengejutkan Beach (1982), menemukan bahwa kelainan sistem imun pada janin akibat kekurangan seng saat dalam kandungan ternyata dapat menetap dan bersifat permanen, bahkan dengan pemberian seng setelah janin lahir, meskipun belum adanya laporan penelitian terkait pengaruh defisiensi seng pada ibu hamil terhadap kejadian stunting anak, namun pengaruh status gizi ibu hamil telah dibuktikan berperan terhadap kejadian stunting anak yang dapat dikenali setelah anak usia 2 tahun kehidupan, besarnya peran mineral seng pada pertumbuhan janin memungkinkan memiliki pengaruh yang sangat signifikan pada ibu hamil dengan kurang energi kronik.

Prevalensi stunting pada anak balita di Indonesia masih tinggi, riset Kesehatan Dasar (RISKESDAS) 2018 melaporkan angka stunting di Indonesia dalam katagori berat $(>30 \%)$ yaitu $30,7 \%$. Stunting dapat dikatakan sebagai kondisi darurat kesehatan karena mengakibatkan rendahnya kualitas sumber daya manusia Indonesia kedepan, buruknya kesehatan masyarakat dan kerugian ekonomi, riset Bank Dunia menggambarkan kerugian ekonomi akibat stunting sebesar 3-11\% dari pendapatan domestik bruto (PDB), akibat lain adalah beban Negara berkaitan dengan angka penyakit tidak menular dan pengurangan IQ sebesar 5-11 poin (Bappenas, 2015). Ricardo dalam Bhutta (2013) melaporkan, balita stunting berkontribusi terhadap 1,5 juta (15\%) kematian anak di dunia dan menyebabkan 55 juta kehilangan masa hidup sehat setiap tahun, ibu hamil kurang energi kronik akan mempengaruhi status kesehatan secara umum, termasuk kurang nutrisi spesifik seperti kurang mineral seng dalam serum ibu. Kekurangan seng selama kehamilan akan berpengaruh buruk terhadap perkembangan janin. Seng dalam per-tumbuhan janin dikaitkan dengan replikasi DNA Widya Karya Pangandan Gizi (WNPG) tahun 2004 merekomendasikan pertambahan kebutuhan seng pada ibu hamil hingga 9,8mg/hari pada trimester ketiga, total kebutuhan seng ibu hamil menjadi 19,8 mg (kebutuhan orang dewasa tidak hamil 10 $\mathrm{mg}$ /hari).

Kandungan seng pada bahan makanan cukup tinggi pada hewani, dalam bahan pangan seng terikat dengan protein, bahan pangan sumber laut termasuk jenis pangan yang memiliki kandungan seng yang cukup tinggi, selain unggas dan mamalia, selain itu mineral seng juga dapat ditemukan pada jenis sayuran seperti daun kelor, terdapat $137 \mathrm{mg}$ seng dalan 100 gr bdd pada daun kelor (Hermansyah, dkk, 2014), mengkaji pemanfaatan ikan layang dan daun kelor dalam penelitian ini karena memiliki harga yang relative murah dan selalu tersedia di pasaran setiap waktu. Puwatu merupakan wilayah daratan yang cukup jauh dari pesisir, sehingga akses bahan pangan seperti ikan sangat tergantung ketersediaannya di pasaran.

\section{METODE PENELITIAN}

Penelitian ini merupakan penelitian eksperimen dengan menggunakan rancangan prepost test, penelitian ini telah dilakukan di Kecamatan Puuwatu Kota Kendari Sulawesi Tenggara, populasi dalam penelitian adalah seluruh ibu hamil kurang energi kronik di wilayah kerja Puskesmas Puuwatu, sampel dalam penelitian ini adalah ibu hamil yang mengalami kurang energy kronik, yang diambil secara total sampling dan dibagi dalam dua kelompok yaitu kelompok kasus dan kelompok control. Variabel depende: Kadar seng ibu hamil. Variabel Independen: Formulasi makanan tambahan, selanjutnya definisi operasionalnya sebagai berikut:

Tabel 1. Variabel dan Definisi Operasional

\begin{tabular}{|c|c|c|}
\hline No & Variabel & Defenisi Operasional \\
\hline 1. & Formulasi & $\begin{array}{l}\text { Bentuk produk makanan yang meru- } \\
\text { pakan campuran fisik antara bahan } \\
\text { utama dan bahan tambahan yang tidak } \\
\text { aktif, menghasilkan bentuk dan kom- } \\
\text { posisi gizi tertentu yang penggunaan- } \\
\text { nya dalam bentuk porsi. }\end{array}$ \\
\hline 2. & $\begin{array}{l}\text { Formula } \\
\text { Nugget }\end{array}$ & $\begin{array}{l}\text { Menyusun bahan makanan mengg- } \\
\text { unakan ukuran yang tepat untuk } \\
\text { memenuhi kebutuhan nugget ikan } \\
\text { layang dengan penambahan daun } \\
\text { kelor untuk memenuhi } 200 \text { kalori, } 20 \\
\text { gr protein dan } 19,5 \text { mg seng. }\end{array}$ \\
\hline 3. & $\begin{array}{l}\text { Kadar } \\
\text { seng }\end{array}$ & $\begin{array}{l}\text { Jumlah dari unsur kimia anorganik } \\
\text { yang disingkat Zn dimana dalam } \\
\text { terikat dengan berbagai molekul } \\
\text { protein dan asam amino yang diukur } \\
\text { dengan metode HPLC dalam satuan } \\
\text { mg/l menggunakan darah vena } \\
\text { medianacubity. }\end{array}$ \\
\hline 4. & $\begin{array}{l}\text { Ikan } \\
\text { layang }\end{array}$ & $\begin{array}{l}\text { Ikan layang (Decapterus spp) me- } \\
\text { rupakan salah satu sumberdaya ikan } \\
\text { pelagis kecil yang memiliki potensi dan } \\
\text { nilai ekonomis tinggi. }\end{array}$ \\
\hline 5. & $\begin{array}{l}\text { Daun } \\
\text { kelor }\end{array}$ & $\begin{array}{l}\text { Tanaman kelor (Moringa oleifera) } \\
\text { merupakan sejenis tumbuhan dari } \\
\text { suku Moringaceae. }\end{array}$ \\
\hline 6 & $\begin{array}{l}\text { Ibu hamil } \\
\text { KEK }\end{array}$ & $\begin{array}{l}\text { Suatu keadaan dimana status gizi } \\
\text { seseorang yang buruk terjadi dalam } \\
\text { kurun waktu lama dan disebabkan } \\
\text { karena kurangnya konsumsi pangan }\end{array}$ \\
\hline
\end{tabular}


sumber energy yang ditandai dengan

hasil pengukuran LILA $<23,5 \mathrm{~cm}$.

Data yang dikumpulkan dalam penelitian ini adalah data primer dan sekunder, data primer diperoleh melalui wawancara langsung dengan menggunakan kuesioner meliputi identitas responden (umur, tinggi badan, berat badan, paritas, IMT, LILA serta pekerjaan), riwayat kehamilan dan asupan zat gizi yang diperoleh dengan menggunakan metode recall $2 \times 24$ jam selama 2 hari, sedangkan kadar seng dan kadar produk pangan nugget dari ruang laboratorium UHO serta data sekunder meliputi profil Puskesmas. Instrumen yang digunakan dalam penelitian ini alat ukur tinggi badan (microtoice), pengukur berat badan (timbangan injak digital), recaal $2 \times 24$ jam dengan formulir reccal konsumsi, kadar seng dengan menggunakan metode HPLC dan pita LILA, pengawasan kualitas data dilakukan untuk menjamin bahwa data yang di kumpulkan sesuai dengan fakta yang ditemukan di lapangan. Data yang terkumpul akan diproses mengikuti tahapan entri data editing, data kemudian di analisis menggunakan uji beda test.

\section{HASIL DAN PEMBAHASAN}

\section{A. Hasil Penelitian}

Pengaruh Pemberian Makanan Tambahan nugget dengan Formula ikan Layang dengan Penambahan Tepung Daun Kelor terhadap Kenaikan Kadar Seng Ibu Hamil KEK di Kecamatan Puuwatu.

\section{a) Analisis Bivariat}

1) Uji Normalitas

Uji normalitas dilakukan pada skor data pre-test dan post-test kedua kelompok sampel, hal ini bertujuan untuk mengetahui kenormalan sebaran data-data tersebut sebagai prasyarat pengujian hipotesis, analisis statistik yang digunakan dalam penelitian ini adalah uji Kolmogorof-Smirnov yang dihitung dengan bantuan program SPSS 20.0 for windows, dalam pengujian normalitas, peneliti menggunakan parameter nilai probabilitas (sig) sebagai acuan dengan ketentuan jika nilai probabilitas (sig) $>0,05$ maka data tersebut terdistribusi secara normal, sementara jika nilai probabilitas $(\mathrm{sig})<0,05$ maka data tersebut tidak terdistribusi secara normal.

\section{2) Uji Hipotesis}

Pengujian hipotesis dilakukan dengan memakai independent t-test, analisis inde-pendent t-test terhadap pre-tes akan me-nunjukkan garis besar perbedaan kadar seng di antara kedua kelompok eks-perimen (ibu hamil) sebelum perlakuan, sementara analisis independent t-test terhadap post-tes angket akan menunjuk-kan perbedaan peningkatan kadar seng pada kedua kelompok eksperimen (ibu hamil), dalam hal ini data pre dan post test merupakan indikator peningkatan atau perubahan kadar seng dengan membandingkan perubahan kadar tersebut sebelum perlakuan dan setelah perlakuan, hasil analisis independent t-test terhadap pre-tes pada kasus dan kontrol di peroleh nilai sign. 0,739 $(>0,05)$ sehingga dapat dikatakan bahwa secara umum tidak terdapat perbedaan kadar seng yang signifikan kedua kelompok sampel, sementara berdasarkan analisis independent t-test terhadap post-test diperoleh nilai sign. $0,034(>0.05)$, sehingga dapat dikatakan bahwa ada pengaruh pemberian nugget terhadap kadar seng ibu hamil.

\section{B. Pembahasan}

Adapun uraian hasil penelitian berikut dalam bentuk bahasan yaitu:

1) Karakteristik sampel

Penelitian ini dilakukan di Wilayah Kecamatan Puwatu Kabupaten Kendari, sampel penelitian ini adalah ibu hamil yang terdiri dari dua kelompok yaitu ibu hamil KEK sebanyak 10 orang sebagai kelompok kasus dan kelompok kontrol juga terdiri dari 10 orang ibu hamil, dari 10 orang ibu hamil KEK 1 orang diantaranya berumur dibawah 20 tahun dan 9 orang berumur 20 tahun keatas sedangkan pada kelompok ibu hamil yang tidak KEK semuanya berumur 20 tahun keatas dengan pekerjaan pada umumnya sebagai ibu rumah tangga, namun pada kelompok kontrol terjadi drop out atau mengundurkan diri dan tidak dapat menyelesaikan proses pemberian PMT sampai selesai sebanyak empat (4) orang. Adapun frekuensi pemberian PMT nugget ini telah diberikan kepada kedua kelompok sampel sebanyak 35 kali pemberian yang semula direncanakan sebanyak 45 kali pemberian mengingat karena waktu efektif penelitian yang tidak memungkinkan lagi. 
Pada minggu pertama penelitian ini diawali dengan recall konsumsi 2x24 jam baik pada kelompok ibu hamil KEK maupun pada kelompok ibu hamil non KEK, adapun hasil reccallnya adalah untuk kelompok ibu hamil KEK rata-rata asupan energi 2812,28 kkal, protein 90,76 gr, lemak 56,46 gr dan KH 497,76 gr, sedangkan untuk kelompok ibu hamil non KEK adalah asupan energi rata-rata $1156,25 \mathrm{kkal}$, protein $45,23 \mathrm{gr}$, lemak 22,83 gr dan KH 191,46 gr, bila dibandingkan dengan rata-rata asupan nutrisi dari kedua kelompok ibu hamil tersebut menunjukkan bahwa asupan nutrisi dari kelompok ibu hamil KEK justru jauh lebih tinggi dua kali lipat dibanding rata-rata asupan pada kelompok ibu hamil tidak KEK.

\section{2) Proses Pembuatan}

Pengembangan nugget dengan formula ikan layang dengan penambahan tepung daun kelor dengan PMT nugget dengan formula ikan layang tanpa penambahan tepung daun kelor, pengembangan formulasi nugget ikan layang dengan penambahan tepung daun kelor ini adalah untuk memenuhi tuntutan kebutuhan ibu hamil setiap hari yaitu 200 kalori, 20 gr protein dan 19,5 mg seng. Proses pembuatan nugget formula ini sebagaimana yang telah di uraikan sebelumnya (alur pembuatan), tahap pertama dengan membuat nugget berdasarkan pada resep pertama dengan penambahan tepung daun kelor sebanyak $240 \mathrm{gr}$, namun hasilnya tidak di sukai oleh ibu hamil kemudian pada tahap pembuatan kedua penambahan tepung daun kelor di kurangi menjadi 150 gr sampai akhirnya penambahan tepung daun kelor tinggal 45 gr (resep terakhir yang dipakai secara lengkap dapat dilihat pada lampiran ), sehingga daya terima ibu hamil lebih baik, sementara pembuatan nugget untuk ibu hamil kelompok kontrol di buat berdasarkan resep standart tampa penambahan tepung daun kelor. Formula nugget ini diberikan kepada ibu hamil 2-3 kali dalam seminggu untuk menghindari kejenuhan atau kebosanan dari sampel, adapun porsi 1 kali pembe-rian sebanyak rata-rata-4 potong dengan berat perporsi 40-50 gram dan komposisi gizinya adalah sebagai berikut: energi 119,7 kkcl, protein $17,8 \mathrm{gr}$, lemak 1,9 gr dan zink $0,5 \mathrm{mg}$.
Berdasarkan hasil analisis di atas, dalam 1 kali pembuatan untuk 10 orang kelompok kasus ( jumlah bahan / resep terlampir) PMT nugget ini ini memberikan sumbangan terbesar pada energi, yakni sebesar $1197 \mathrm{Kcl}$, protein $178,2 \mathrm{gr}$, lemak 19,0 gr, Hidrat arang 77,5 gr dan Zink 5,4 mg, dengan pemberian PMT nugget formula setiap sampel (intervensi kelompok kasus) dengan pemberian selama 35 hari, maka ini berarti setiap kali pemberian sampel mendapatkan tambahan kontribusi zat gizi berupa Energi sebanyak 119,7 Kcl, Protein 17,8 gr, Lemak 1,9 gr Kh 7,74 gr serta seng 0,5.mg, sedangkan pada kelompok kontrol resep pemberian nugget sama dengan bahan- bahan pada nugget kelompok kasus yang membedakan hanya tidak ada penambahan tepung daun kelor.

3) Karakteristik Kimia

Formula Nugget Ikan Layang dengan Penambahan Daun Kelor Berdasarkan hasil uji proksimat menunjukkan kadar air $20,613 \%$ kadar abu $0,642 \%$ protein 8,081 $\%$ lemak 18,822 serat kasar 3,5 dan zink 9,390 dengan adanya hasil pengujian ini membuktikan bahwa dengan adanya penambahan ikan layang dan tepung daun kelor dapat memperkaya zat gizi yang terkandung dalam nuget yang sangat dibutuhkan oleh ibu hamil KEK dan non KEK.

4) Gambaran Kadar Seng Ibu Hamil yang Mengalami Kurang Energi Kronik

Adapun gambaran secara umum dari hasil penelitian ini sebelum dan sesudah intervensi baik dari kelomok kasus (ibu hamil KEK) maupun dari kelompok kontrol (ibu hamil tidak KEK) pertama berdasarkan hasil pengukuran antropometri menunjukkan bahwa dari 10 orang sampel ibu hamil KEK rata-rata berat badannya sebelum diintervensi adalah 45,9 $\mathrm{kg}$ setelah diintervensi berat badan rata-rata naik menjadi 53,26 sehingga terjadi kenaikan berat badan rata-rata sebesar 6 , $86 \mathrm{~kg}$, sementara LILA juga terjadi penambahan yaitu dari rata-rata $22,14 \mathrm{~cm}$ menjadi $22,7 \mathrm{~cm}$ setelah diintervensi dengan pemberian PMT nagget dengan formula ikan layang dengan penambahan tepung daun kelor, sedangkan pada kelompok kontrol juga terjadi kenaikan berat badan dari rata-rata $62 \mathrm{~kg}$ sebelum diintervensi naik menjadi rata-rata $69,3 \mathrm{~kg}$ 
setelah diintervensi (dari 6 orang sampel yang di timbang berat badannya, 4 orang diantaranya droup out atau mengundurkan diri), sementara hasil pengukuran LILA dari 10 sampel sebelum diintervensi ratarata LILA nya adalah $26,97 \mathrm{~cm}$ naik menjadi rata-rata $28 \mathrm{~cm}$ setelah di berikan PMT nugget formula ikan layang tanpa penambahan daun kelor.

Berdasarkan hasil pengukuran antropo metri pada berat badan pada kelompok kontrol terdapat 2 sampel yang menarik karena terjadi perbedaan berat badan yang ekstrim dari sampel lainya yaitu sampel 10 yang tadinya berat badannya sebelum diintervensi adalah $45 \mathrm{~kg}$ naik menjadi 55 kg setelah intervensi, dibandingkan dengan sampel yang satunya justru terjadi sebaliknya yaitu berat badannya dari 70 $\mathrm{kg}$ turun menjadi $62,3 \mathrm{~kg}$ setelah intervensi dengan pemberian PMT nugget formula ikan layang tanpa penambahan tepung daun kelor. Salah satu keterbatasan dalam penelitian ini karena peneliti tidak dapat menganalisis lebih jauh secara tepat penyebab terjadinya penurunan berat badan yang drastis dari sampel tersebut, namun kemungkinan karena PMT nugget formula ini mengandung serat yang tinggi sehingga apabila di konsumsi dengan baik, maka dapat menurunkan berat badan sampel yang kegemukan.

Selanjutnya untuk hasil uji laboratorium kadar seng dalam serum darah pada kelompok ibu hamil KEK sebelum dan sesudah intervensi menunjukkan bahwa rata-rata kadar seng sebelum intervensi sebesar $200,5072 \mathrm{mg} / \mathrm{L}$ naik menjadi ratarata $212,6355 \mathrm{mg} / \mathrm{L}$ setelah intervensi yang berarti terjadi kenaikan rata-rata kadar seng ibu hamil KEK sebesar 12,6 $\mathrm{mg} / \mathrm{L}$, sedangkan pada kelompok kontrol menunjukkan bahwa kadar seng dalam serum darah ibu hamil sebelum diinrevensi rata-rata sebesar 201,6607 naik menjadi rata-rata 204,6048 setelah pemberian nugget formula ikan layang tanpa penambahan tepung daun kelor, bila di bandingkan dengan kenaikan kadar seng ibu hamil pada kelompok kontrol, maka ternyata kenaikan kadar seng dalam darah ibu hamil yang KEK lebih tinggi yaitu terjadi kenaikan rata-rata sebesar 12,6 $\mathrm{mg} / \mathrm{L}$, hal ini memang sangat memungkinkan karena kandungan seng pada PMT nugget formula cukup tinggi setelah penambahan tepung daun kelor, dan selama penelitian berlangsung sampel tersebut juga menkonsumsi dari sumber makanan lain yang mengandung seng.

5) Pengaruh Pemberian Nugget Ikan Layang dengan Penambahan Tepung Daun Kelor terhadap Kadar Seng Ibu Hamil yang Kekurangan Energi Kronik

Berdasarkan hasil uji laboratorium menunjukkan bahwa terjadi penambahan kadar seng dalam darah ibu hamil KEK setelelah diintervensi yaitu rata-rata $200,5072 \mathrm{mg} / \mathrm{L}$ sebelum di intervensi dengan pemberian PMT nugget formula ikan layang dengan penambahan tepung daun kelor naik menjadi rata-rata 212, $63554 \mathrm{mg} / \mathrm{L}$ setelah diintervensi yang berarti bahwa ada kenaikan kadar seng sebesar rata-rata $12,6 \mathrm{mg} / \mathrm{L}$, maka secara statistik ada pengaruh secara signifikan, sedangkan pada kelompok kontrol di tunjukkan dengan hasil analisis independent t-test terhadap pre-tes pada kasus dan kontrol di peroleh nilai sign. 0,739 $(>0,05)$ sehingga dapat dikatakan bahwa tidak ada perbedaan kadar seng yang signifikan kedua kelompok sampel. Sementara berdasarkan analisis independent t-test terhadap post-test, diperoleh nilai sign. $0.034(<0.05)$, sehingga dapat dikatakan bahwa ada pengaruh pemberian nugget formula ikan layang dengan penambahan tepung daun kelor terhadap kadar seng ibu hamil. Hasil penelitian ini sejalan dengan hasil penelitian D.A Liona dewi dkk, yang menunjukkan adanya perbedaan yang signifikan pada kadar serum zink pada kelompok perlakuan dengan kelompok kontrol $\mathrm{p}=0,000<0,05$.

Untuk meningkatkan daya terima konsumsi nugget pada ibu hamil KEK maka di lakukannya pengurangan konsentrasi penambahan tepung daun kelor pada produk pertama yaitu dari 240 gram dikurangi menjadi 150 gram, kemudian yang terakhir yang bisa diterima oleh ibu hamil KEK dengan konsentrasi 45 gr tepung daun kelor. Hal ini dilakukan karena pertimbangan daya terima sampel ibu hamil KEK yang rendah sehingga di kwatirkan PMT yang diberikan tidak bisa dihabiskan pada setiap pemberian, cita 
rasa yang agak keras dengan bau dari tepung daun kelor yang sedikit menyengat dikwatirkan daya terima sampel kurang, bahkan secara teori disebutkan bahwa untuk mendapatkan hasil dari uji laboratoriun yg maksiamal, maka idealnya pemerikasan sampel darah atau rambut diadakan pengujian 2-3 bulan kedepan setelah pemberian PMT terakhir, sedangkan pada kelompok kontrol yang diberikan PMT nugget dengan konsentrasi bahan standart (resep lengkap dapat dilihat pada lampiran penelitian) sehingga daya terima ibu hamil non KEK lebih tinggi dan dapat di konsumsi dengan baik, adapun kenaikan kadar seng dalam darah kelompok kontrol yang juga tinggi, hal ini disebabkan karena kemungkinan si ibu banyak menkonsumsi sayur dari daun kelor dan dari sumber makanan yang lain yang mengandung seng. Demikianlah hasil penelitian ini dengan segala kekurangannya diharapkan dapat membantu memberikan solusi bagi pemerintah untuk secara dini menangani dan menanggulangi masalah stunting di Indonesia dengan memperbaiki status gizi dan kondisi kesehatan secara umum kepada ibu hamil khususnya pada ibu hamil yang menderita kekurangan energi kronik (KEK).

Adapun kelemahan dari penelitian ini adalah kemungkinan nugget yang diberikan kepada ibu hamil KEK tidak sepenuhnya dihabiskan, pemeriksaan laboratorium untuk kadar seng dengan memakai sampel rambut (jarak atau waktu antara pemeriksaan sampel rambut dengan pemberian nugget yang terakhir yang dekat dan sampel yang sedikit.

\section{SIMPULAN DAN SARAN}

\section{A. Simpulan}

Berikut disajikan beberapa kesimpulan dari proses penelitian ini:

1. Hasil pengembangan pembuatan nugget formula ikan layang dengan penambahan tepung Daun kelor dengan bahan sebagai berikut: ikan layang $700 \mathrm{gr}$, tepung kelor 45 gr, tepung terigu 50 gr, telur ayam bagian putih 40 gr, gula pasir 5 gr , lada bubuk 1 bks, bawang putih 10 siung, garam 1 sendok teh dan minyak goreng 50 gr, adapun nilai gizinya adalah energi sebesar $1197 \mathrm{Kcl}$, protein 178,2 gr, lemak 19,0 gr, Hidrat arang 77,5 gr dan Zink 5,4 mg.
2. Berdasarkan hasil uji proksimat (1 porsi nugget), mengandung kadar air 20,613\%, kadar abu 0,642 \%, protein 8,081 \%, lemak $18,822 \%$ serat kasar 3,5 \% dan zink 9,3\%.

3. Berdasarkan hasil uji laboratorium kadar seng dalam serum darah pada kelompok ibu hamil KEK sebelum dan sesudah intervensi menunjukkan bahwa rata-rata kadar seng sebelum intervensi sebesar $200,5072 \mathrm{mg} / \mathrm{L}$ naik menjadi rata-rata $212,6355 \mathrm{mg} / \mathrm{L}$ setelah intervensi yang berarti terjadi kenaikan rata-rata kadar seng ibu hamil KEK sebesar 12,6, mg/L.

4. Secara statistik ada pengaruh yang signifikan dengan pemberian PMT nugget formula ikan layang dengan penambahan tepung daun kelor terhadap kenaikan kadar seng dalam serum darah ibu hamil KEK dengan nilai sig 0,034 $(<0,05)$ dan terjadi kenaikan berat badan rata-rata 6,86 $\mathrm{kg}$ dan penambahan LILA pada ibu hamil KEK sebesar 0,61 cm.

\section{B. Saran}

Adapun saran-saran yang diajukan dalam penelitian ini antara lain:

1. Kepada ibu hamil KEK untuk tetap mengkonsumsi daun kelor selama hamil baik dalam bentuk nugget, sayur dan sumber makanan lain yang banyak mengandung zink.

2. Kepada petugas gizi di Puskesmas senantiasa memberikan penyuluhan secara rutin kepada ibu hamil tentang manfaat daun kelor dan pentingnya zink selama masa kehamilan.

3. Kepada peneliti selanjutnya untuk meningkatkan konsentrasi penambahan tepung daun kelor sampai pada batas yang dapat diterima oleh ibu hamil, dan meningkatkan frekwensi pemberian PMT dengan jumlah sampel yang lebih banyak.

\section{DAFTAR RUJUKAN}

Afrisianti, D.W. 2010. Kualitas kimia dan organoleptik Nugget Daging Kelinci dan penambahan tepung tempe. Skripsi. Program studi peternakan. Fakultas pertanian. Surakarta: Universitas 11 maret.

Antonio Rivaldi. 2019. Daya Terima Nugget Ikan Gabus dengan Penambahan Wortel. Poltekkes Kemenkes Kendari Jurusan Gizi.

Aristawati, R. 2013. Substitusi Tepung Tapioka (Manihot esculenta) Dalam Pembuatan 
Takoyaki. Jurnal Teknosains Pangan Vol 2 No 1: 56-63.

Chaffeea BW, King JC. 2012. Effect of Zinc Supplementation on Pregmamcy and Infant Outcomes. A Systematic Review. Pediatri Perinal Epidemiol. 26(1) : 118.

D,A. Liona Dewi dkk. Pengaruh Pemberian Zink pada Ibu Hamil KEK Trimester III terhadap Kadar Zink dan Retinol Serum Saat Nifas di Kabuaten Bojonegoro.

Ervinawati, dkk. 2018. Determinan Kekurangan Energi kronis (KEK) Ibu Hamil di Puskesmas Lubuk Muda. STIKES Hang Tuah Pekanbaru. Jurnal Kesehatan Komunitas 2018;4(3):120-125.

Fitriana Dyah Primadani. 2016. Faktor-faktor yang Mempengaruhi Kejadian KEK pada Ibu Hamil di Puskesmas Baturraden di Kabupaten Banyumas. Universitas Muhammadiyah Purwokerto.

Hardinsyah dan Supariasa. 2016. Ilmu Gizi Teori dan Aplikasi. Jakarta : ECG.

Linturan, R.M.W., dkk. 2015. Hubungan antara Kadar Seng dalam Serum dengan Fungsi Eksekutif pada Anak dengan Gangguan Pemusatan Perhatian dan Hiperaktivitas (GPPH). Departemen Psikiatri Fakultas Kedokteran Universitas Indonesia/Rumah Sakit Dr. Cipto Mangunkusumo, Jakarta. Vol. 17, No. 4.

Marwati, dkk. 2017. Hubungan Tingkat Asupan Energi, Protein, Zat Besi, (Fe), Seng (Zn), Asam Folat, dan Vitamin A Ibu Hamil dengan Kejadian berat Badan Lahir bayi di Wilayah kerja puskesmas Puuwatu Kota Kendari tahun 2017. Fakultas Kesehatan Masyarakat Universitas Halu Oleo, JIMKESMAS VOl.2/no.7/Agustus 2017.
Rukmana, Rahmat. 2012. Budidaya Bawang Putih. Yogyakarta: Kanisius

Rukmana,S,C. 2013. Hubungan Asupan Gizi Dan Status Gizi Ibu Hamil Trimester III Dengan Berat Badan Lahir Bayi Di Wilayah Kerja Puskesmas Suruh. Program Studi Ilmu Gizi Fakultas Kedokteran Universitas Diponegoro Semarang.

Russeng, dkk. 2013. Pengaruh Pemberian Ekstrak Daun Kelor Kepada Ibu Hamil Pekerja Sektor Informasi Terhadap Stress Kerja, Status Gizi, Kerusakan DNA dan Pertumbuhan Bayi. http://repository.unhas.ac.id/handle/123 $456789 / 11964$.

Setijowati Nanik. 2005. Hubungan Kadar Seng Serum Dengan Tinggi Badan Anak Sekolah Dasar Penderita Gaky. Fakultas Kedokteran Universitas Brawijaya Malang. Vol. XXI, No. 1.

Syah M.N.H, dkk. 2012. Status Zat Gizi Mikro (Besi, Asam Folat Dan Seng) Dan Kerusakan Dna Pada Anemia Ibu Hamil Di Kecamatan Bontonompo Dan Bontonompo Selatan Kabupaten Gowa Tahun 2012. Program Studi Ilmu Gizi Fakultas Kesehatan Masyarakat Universitas Hasanuddin. 